\title{
Covid-19: We need to be open about rationing ventilators
}

\section{Caroline Mawer retired public health consultant and urgent care general practitioner}

London, UK

Why aren't we being more explicit about the ever changing problems around ventilators? ${ }^{1-4}$ The Italians warned us. ${ }^{5}$ The New England Journal of Medicine said that volunteers should "shoulder the burden" of explicit rationing. ${ }^{6}$ The National Institute for Health and Care Excellence continues to develop its response. ${ }^{7}$

I don't claim to have definitive "answers," but, decades ago, I led the first explicit rationing of health services in England. Maybe some of the lessons I learnt would be helpful ${ }^{8}$ :

Keep learning from the evidence about direct and indirect costs and benefits. ${ }^{9-12}$ We'll need to collect and share more of this as we go along. But an up-to-date explicitly evidence based policy is much easier for patients, families, and clinicians to accept.

We must be clear about what will be done instead of any rationed intervention. Good quality supportive and palliative care must be immediately available.

Explain the policy clearly-to patients, families, communities, clinicians, and the press. We haven't much time but must have some (fast) involvement.

Protect the clinicians making frontline decisions. Proper buy-in to an up-to-date evidence-based policy will make this easier-both now and to reduce later regrets.

NEJM suggests that a specific volunteer group make disputed decisions. These volunteers must be protected too: the group I led explicitly looked after each other.

Include lay people in decision making. My group was hesitant about this, but we quickly found lay people worth more than their weight in gold. I recommend finding, paying, and supporting the right lay people.

Handling the media (social and other) right helps with the messaging. Get it wrong and the problems will continue through the inevitable inquiry.
Competing interests: I'm being shielded (I prefer to follow the Irish and think of myself as cocooned). Even though I have lots of useful experience, with my sort of ill health retirement, I'm not allowed to volunteer for NHS work. So I'm volunteering to ask one of the questions that no one seems to be asking. Full response at: https://www.bmj.com/content/368/bmj.m1201/rr.

Mahase E. Covid-19: most patients require mechanical ventilation in first 24 hours of critical care. BMJ 2020;368:m1201. 10.1136/bmj.m1201 32209544

2 Davies R. How close is the NHS to getting the 18000 ventilators it needs? Guardian 2020 Apr 14. https://www.theguardian.com/business/2020/apr/14/how-close-is-the-nhs-togetting-the-18000-ventilators-it-needs-coronavirus

3 Pugh R. Covid-19: Manchester Nightingale takes different approach to London. Medscape News UK 2020 Apr 10. https://www.medscape.com/viewarticle/928511

4 Nuki P. Intensive care doctors question "overly aggressive" use of ventilators in coronavirus crisis. Daily Telegraph 2020 Apr 9. https://www.telegraph.co.uk/global-health/scienceand-disease/intensive-care-doctors-question-overly-aggressive-use-ventilators/

5 Parker C. "Every ventilator becomes like gold"- doctors give emotional warnings from Italy's Coronavirus outbreak. World Economic Forum. 9 Mar 2020 https://www.weforum. org/agenda/2020/03/suddenly-the-er-is-collapsing-a-doctors-stark-warning-from-italyscoronavirus-epicentre/

6 Truog RD, Mitchell C, Daley GQ. The toughest triage-allocating ventilators in a pandemic. N Engl J Med 202010.1056/NEJMp2005689 32202721

7 NICE. Covid-19 rapid guideline: critical care in adults. 9 April 2020 https://www.nice.org. uk/guidance/ng159

8 Mawer $\mathrm{C}$. When are we going to talk about rationing ventilators and how to get palliative care right? [electronic response to Mahase E. Covid-19: most patients require mechanical ventilation in first 24 hours of critical care]. BMJ 2020. https://www.bmj.com/content/368/ bmj.m1201/rr

9 Hosali S. The fight against covid-19: whose life counts? British Institute of Human Rights. https://www.bihr.org.uk/blog/the-fight-against-covid-19-whose-life-counts

10 Lockwood S. "It is scary": Inside the "red zone" intensive care unit where NHS staff and patients are battling coronavirus. ITV News 2020 Apr 6. https://www.itv.com/news/202004-06/it-is-scary-inside-the-intensive-care-unit-where-nhs-staff-and-patients-are-battlingcoronavirus/

11 Williams $\mathrm{J}$. Elderly people with coronavirus denied hospital beds and left to die in care homes. Manchester Evening News 2020 Apr 4. https://www.manchestereveningnews.co. uk/news/greater-manchester-news/elderly-people-coronavirus-denied-hospital-18038252

12 Campbell D, Marsh S, Johnson S. Warning as UK coronavirus outbreak leads to sharp rise in deaths at home. Guardian 2020 Apr 16. https:/www.theguardian.com/society/2020/ apr/15/sharp-rise-in-ill-patients-dying-at-home-since-coronavirus-outbreak

Published by the BMJ Publishing Group Limited. For permission to use (where not already granted under a licence) please go to http://group.bmj.com/group/rights-licensing/ permissions 